\title{
Sorption of anthropogenic radionuclides onto river sediments and suspended solids: dependence on sediment composition
}

\author{
Eva Juranová ${ }^{1,2}$ (1) Eduard Hanslík ${ }^{1} \cdot$ Silvia Dulanská ${ }^{3} \cdot$ Tomáš Grísa $^{4} \cdot$ Barbora Sedlářová $^{1} \cdot$ Diana Marešová $^{1}$
}

Received: 25 October 2019 / Published online: 1 May 2020

(c) The Author(s) 2020

\begin{abstract}
The purpose of the study is to explore the sorption behaviour of anthropogenic radionuclides in the Vltava River catchment in the Czech Republic, which could be influenced by an assumptive severe nuclear accident. Radionuclide sorption was described by distribution coefficients between water and sediment or suspended solids, respectively. Then, possible correlations between radionuclide sorption and sediment properties were investigated using simple and multiple regressions. The sorption of radionuclides was affected by sediment granularity and mineralogical composition, each radionuclide having its group of influencing sediment parameters.
\end{abstract}

Keywords Sorption $\cdot$ Anthropogenic radionuclide $\cdot$ Hydrosphere $\cdot$ Sediment $\cdot$ Suspended solids $\cdot$ Distribution coefficient

\section{Introduction}

Anthropogenic radionuclides, which are created in the reactor of a nuclear power plant during nuclear reactions, usually do not occur naturally in the environment. They were introduced by human activities, predominantly in the last century during atmospheric nuclear weapons tests and the Chernobyl accident. Nowadays, some of these radionuclides, namely caesium 137 and strontium 90, are still present in the water environment in low but measurable amounts [1-5].

Electronic supplementary material The online version of this article (https://doi.org/10.1007/s10967-020-07174-w) contains supplementary material, which is available to authorized users.

Eva Juranová

eva.juranova@vuv.cz

1 T. G. Masaryk Water Research Institute, Public Research Organization, Podbabská 2582/30, 16000 Prague 6, Czech Republic

2 Faculty of Science, Institute for Environmental Studies, Charles University in Prague, Albertov 6, 12843 Prague 2, Czech Republic

3 Department of Nuclear Chemistry, Faculty of Natural Sciences, Comenius University, Mlynska Dolina, Ilkovičova 6, 84215 Bratislava, Slovakia

4 NUVIA a.s., Modřínová 1094, 67401 Třebíč, Czech Republic
After the Fukushima nuclear accident in 2011, where radioactive contamination was released into the surrounding environment [5-8], great attention has been focused on nuclear safety all over the world. The Czech Republic is no different. Despite the fact that both Czech nuclear power plants are considered safe, as proved by stress tests [9], nuclear safety also concerns the very improbable case of a severe accident, when radioactive material is released outside the plant.

When surface water is polluted, radioactive contaminants are transported together with the water along the river course. During this migration, radionuclides can be either fixed onto solids suspended in water, which can settle afterwards, or they are sorbed directly onto sediments already deposited on the riverbed [10]. Experience with the old radioactive contamination indicates that sorption onto sediments plays a significant role in the migration of radionuclides in the hydrosphere $[1,11]$. These sorption processes influence the migration of radionuclides in the environment and their entrance into food chains.

The aim of our study was to describe the influence of sorption on water environment contamination after a hypothetical severe accident at a nuclear power plant. In order to quantify sorption of radionuclides onto solid components of the hydrosphere, bottom sediments and suspended solids, their distribution coefficients were determined using a batch method. Then, correlations of distribution coefficients and sediment composition parameters were studied to detect 
dependences between sorption of anthropogenic radionuclides and sediment quality. This should reveal the types of sediments that would tend to retain incidental radioactive contamination if a severe nuclear accident occurred. Further, it should enable better generalization of measured sitespecific sorption data and applying them for other locations.

\section{Methods}

\section{Batch experiments-determination of distribution coefficient}

In this study, sorption of anthropogenic radionuclides was studied along the Vltava and Elbe Rivers in the Czech Republic. Hence, samples of bottom sediments and surface water were collected at 17 locations, as shown in Fig. 1. The studied river course includes stretches of flowing water, stream regulated with weirs and, most of all, a cascade of dams. At these locations, the distribution coefficients of selected anthropogenic radionuclides in sediment-water and suspended solids-water interfaces were determined.

The samples of sediments were collected by a diver from a depth from 1 to $22 \mathrm{~m}$ below the water level, depending on the specific location. The samples of sediments were taken from the upper sediment layer $(0-10 \mathrm{~cm})$

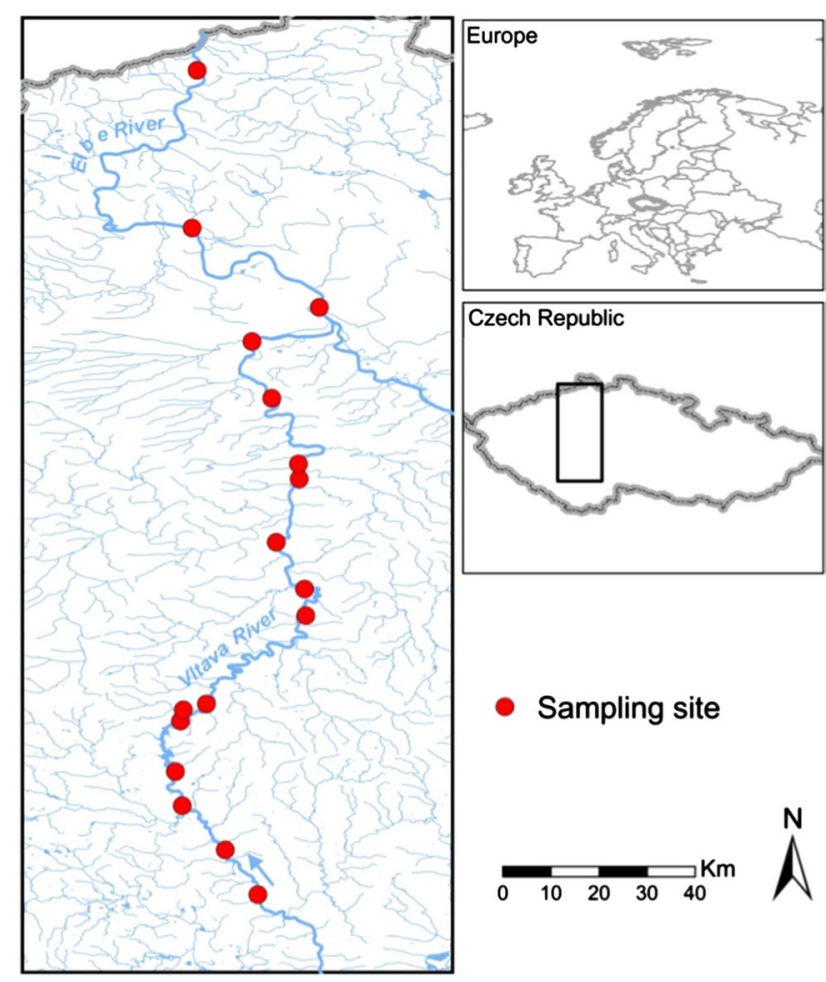

Fig. 1 Location of sites where sediment and surface water samples were collected in amounts sufficient for the experiments (ca. $10 \mathrm{~kg}$ fresh weight). At the same locations, large-volume samples were taken of surface water (100 1) containing suspended solids. Both kinds of samples (sediments and surface water) were transported to a laboratory, where they were stored in a refrigerator and processed promptly.

In general, the batch method used for distribution coefficient determination is described in documents by the International Atomic Energy Agency (IAEA) [12], US Environmental Protection Agency (EPA) [13], and ASTM C1733 - 10 [14]. The method is also widely used in many studies [15-19]. However, the conditions of determination can vary, depending on the requirements and purpose of the study. We optimized the conditions of determination with preliminary experiments, as we published previously [20]. Since sorption depends on a number of factors, it is important to respect the natural conditions of the tested site when conducting the laboratory experiments. The method optimization comprised finding the suitable solid/ liquid ratio and the initial radionuclide activity concentration, sufficient contact time, and the influence of other conditions, such as ambient temperature or mixture $\mathrm{pH}$. These optimised method conditions [20] were used in this study.

To prepare the experimental batch, the wet sediment was placed into vessels in an amount corresponding to $100 \mathrm{~g}$ of dry matter per $1 \mathrm{~L}$ of water. Water contained in the sediment was replenished to the required amount with the matching surface water sampled at the same site. In the case of suspended solids, the surface water was used for preparing the test sample with its natural suspended solids concentration, without any treatment.

Then, the experimental batches (mixtures of solid phase and water) were spiked with a mixture of radionuclides $\left({ }^{131} \mathrm{I},{ }^{134} \mathrm{Cs},{ }^{85} \mathrm{Sr},{ }^{60} \mathrm{Co},{ }^{241} \mathrm{Am},{ }^{139} \mathrm{Ce},{ }^{133} \mathrm{Ba}\right)$ and enclosed in a plastic bottle. Radionuclides and their spiked activities were chosen with regard to the purpose of determining the distribution coefficient-accidental release of radioactive contamination. When selecting suitable radionuclides, several aspects were considered: (1) the selected radionuclides should cover various chemical properties, with an emphasis on the most serious ones $\left({ }^{137} \mathrm{Cs},{ }^{90} \mathrm{Sr}\right.$ and $\left.{ }^{131} \mathrm{I}\right)$; (2) suitability for the gamma-ray spectrometric measurement; (3) convenience for use in the laboratory (relatively short half-life to prevent long-term contamination and availability from the supplier). It was supposed that different nuclides of the same element have the same sorption properties. For example, that is the case with ${ }^{85} \mathrm{Sr}$, which was included into the experiments instead of ${ }^{90} \mathrm{Sr}$ because the latter cannot be measured with gamma-ray spectrometry. In the experimental mixture, the radionuclides were spiked in various initial concentrations $-{ }^{60} \mathrm{Co},{ }^{85} \mathrm{Sr},{ }^{139} \mathrm{Ce}$ and ${ }^{241} \mathrm{Am}$ : $2-5 \mathrm{~Bq} / \mathrm{l} ;{ }^{134} \mathrm{Cs}$ : 20-50 Bq/1; ${ }^{131} \mathrm{I}$ and ${ }^{133} \mathrm{Ba}$ 40-100 Bq/1. 
When the test samples were prepared, they were mixed using an overhead laboratory shaker for $24 \mathrm{~h}$. After mixing, the solid was separated from the liquid phase using vacuum filtration (suspended solids-water) or centrifugation, followed by vacuum filtration (sediments-water).

The radionuclide amounts were measured with gammaray spectrometry using the standard method according to ISO 10703: 2007 [21], an analytical method suitable for all the monitored radionuclides. For that, Canberra-Packard germanium (HPGe) detectors were used. The detectors were calibrated using ${ }^{152} \mathrm{Eu}$ standard (energy calibration) and certified source containing a mixture of artificial radionuclides (efficiency calibration). We measured the radionuclides of interest in both separated phases-in water and in sediment or suspended solids - to eliminate the influence of radionuclide sorption onto the vessel walls or other parts of the apparatus. Measuring times varied from several hours to days, depending on the radionuclide amount in the measured phases.

The distribution coefficient was evaluated from the experimental data set as a slope of linear regression of the measured $a_{e}-c_{e}$ relationship that intersects the beginning of the coordinate system (according to Eq. (1)) [12]:

$K_{D}=\frac{a_{e}}{c_{e}}$

where $K_{D}$ is distribution coefficient $(1 / \mathrm{kg}), a_{e}$ radionuclide specific activity sorbed on solid phase in equilibrium (Bq/ $\mathrm{kg}), c_{e}$ radionuclide activity concentration in water in equilibrium $(\mathrm{Bq} / \mathrm{l})$.

\section{Sediment and water quality}

To acquire information on sediment quality, samples were sent to the Geomechanical Laboratory, ARCADIS CZ. They were analysed to obtain the granulometric curve for evaluation of grain size median $\left(d_{50}\right)$ and silt content (see Fig. 2); further, mineralogical composition was determined using $\mathrm{X}$-ray diffraction (RTG) and petrographic analysis (PL). For further evaluation, the following parameters were used (see the measured values summary in Table 1):

- grain size median $-d_{50}(\mathrm{~mm})$

- content of silt, grain size lower than $0.063 \mathrm{~mm}(\%)$

- content of quartz (\%)

- content of feldspar (\%)

- content of mica (\%)

- content of organic matter $(\%)$

Similar analysis could not be conducted for suspended solids because the number of samples was not sufficient for determination.

Table 1 Summary of sediment quality collected at 17 locations, used for distribution coefficient determination

\begin{tabular}{llllll}
\hline Parameter & & $\begin{array}{l}\text { Arith- } \\
\text { metic } \\
\text { mean }\end{array}$ & SD & Minimum & Maximum \\
\hline $\mathrm{d}_{50}$ & $(\mathrm{~mm})$ & 0.38 & 0.23 & 0.08 & 0.9 \\
Silt & $(\%)$ & 16 & 13 & 2 & 46 \\
Mica (PL) & $(\%)$ & 8 & 6 & 0 & 21 \\
Organic matter (PL) & $(\%)$ & 13 & 11 & 0 & 36 \\
Quartz (RTG) & $(\%)$ & 78 & 13 & 35 & 90 \\
Feldspar (PL) & $(\%)$ & 10 & 8 & 0 & 30 \\
Feldspar (RTG) & $(\%)$ & 14 & 7 & 4 & 32 \\
\hline
\end{tabular}

Fig. 2 Example of a granulometric curve of one of sampled sediment and evaluation of silt content and $\mathrm{d}_{50}$

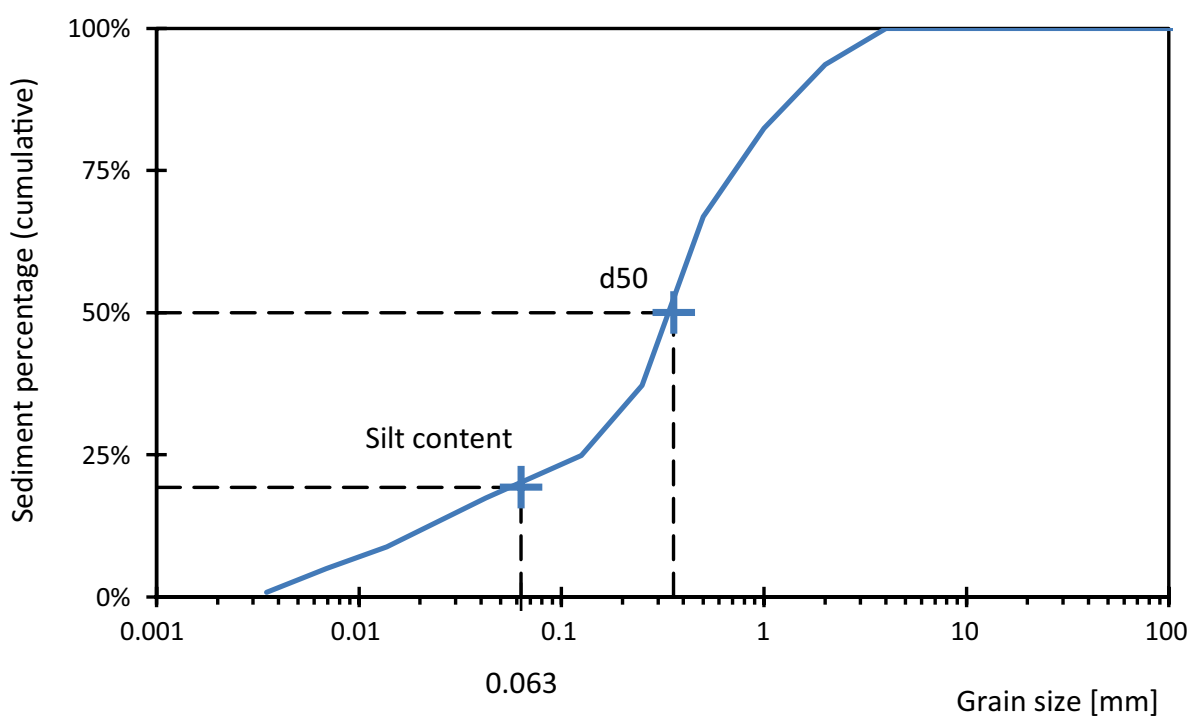


To get basic information on water quality used for the experiments, analysis was performed by the laboratory of the T. G. Masaryk Water Research Institute. Surface water quality is summarized in Table 2.

\section{Statistical evaluation of sorption dependence on sediment quality}

The statistical comparison of sorption dependence on sediment quality can be performed by applying a rigorous approach to linear regression using regression triplet (program QC-EXPERT- Trilobyte, Pardubice, Czech Republic and ADSTAT Trilobyte, Pardubice, Czech Republic).

The model proposed for the simple linear regression was:

$y=b_{0}+b_{1} x$

where $y$ is dependent variable (sorption of the radionuclide described with the $K_{D}$ ), $x$ independent variable (parameter of the sediment quality), $b_{0}, b_{1}$ regression coefficients.

Three statistical measures were used to evaluate the goodness of fit of models and to compare them. The coefficient of determination $R^{2}$ is the proportion of variance in the dependent variable that is predictable from the independent variable. Therefore, it describes how well the regression predictions approximate to real data points. Moreover, the Fisher-Snedecor test (F criterion) is used as a formal statistical test for the relationship between the proposed model and the dependent variable. Therefore, it describes whether the correlation between the model and the dependent variable is statistically significant. Thus, only models with F criteria

Table 2 Summary of water quality collected at 17 locations, used for distribution coefficient determination

\begin{tabular}{llllll}
\hline Parameter & & $\begin{array}{l}\text { Arithme- } \\
\text { tic mean }\end{array}$ & SD & Minimum & Maximum \\
\hline $\mathrm{pH}$ & - & 7.4 & 7.5 & 7.0 & 9.7 \\
Conductivity & $(\mathrm{mS} / \mathrm{m})$ & 28 & 8 & 17 & 43 \\
Suspended solids & $(\mathrm{mg} / \mathrm{l})$ & 10 & 7 & 1 & 24 \\
$\mathrm{TOC}^{-}$ & $(\mathrm{mg} / \mathrm{l})$ & 9.6 & 3.0 & 6.8 & 18.3 \\
$\mathrm{Cl}^{-}$ & $(\mathrm{mg} / \mathrm{l})$ & 17 & 6 & 8 & 29 \\
$\mathrm{SO}_{4}{ }^{2-}$ & $(\mathrm{mg} / \mathrm{l})$ & 31 & 11 & 19 & 49 \\
$\mathrm{NO}_{3}{ }^{-}$ & $(\mathrm{mg} / \mathrm{l})$ & 9.3 & 3.8 & 3.9 & 16.1 \\
$\mathrm{Na}^{2}$ & $(\mathrm{mg} / \mathrm{l})$ & 13.5 & 4.1 & 8.0 & 20.5 \\
$\mathrm{Ca}^{-}$ & $(\mathrm{mg} / \mathrm{l})$ & 29 & 10 & 18 & 50 \\
$\mathrm{Mg}$ & $(\mathrm{mg} / \mathrm{l})$ & 7.1 & 1.8 & 4.8 & 10.6 \\
$\mathrm{Ba}$ & $(\mu \mathrm{g} / \mathrm{l})$ & 34 & 6 & 23 & 41 \\
$\mathrm{Co}$ & $(\mu \mathrm{g} / \mathrm{l})$ & $<1$ & & & \\
$\mathrm{Sb}$ & $(\mu \mathrm{g} / \mathrm{l})$ & $<2$ & & & \\
$\mathrm{Se}$ & $(\mu \mathrm{g} / \mathrm{l})$ & $<4$ & & & \\
$\mathrm{Sr}$ & $(\mu \mathrm{g} / \mathrm{l})$ & 140 & 60 & 80 & 260 \\
\hline
\end{tabular}

over a critical value were considered. As described, both measures suggest statistical significance of the estimated models. The Akaike information criterion (AIC) served here for estimating the relative quality of the proposed models. It is useful for comparison between two models because it describes how well the model fits the data set without overfitting it. The model with the lowest AIC score is more likely to minimize information loss.

For multiple regression, calculations were performed using software ' $R$ ' (R: A Language and Environment for Statistical Computing) with 'leaps' package (regression subset selection including exhaustive search).

The linear model for the multiple regression was proposed as follows:

$y=b_{0}+b_{1} x_{1}+\cdots+b_{n} x_{n}$

where $y$ is dependent variable (sorption of the radionuclide described with the $\left.K_{D}\right), x_{1}-x_{n}$ independent variable (parameter of the sediment quality), $b_{0}-b_{n}$ regression coefficients.

The selected models were validated using k-fold crossvalidation. The statistical significance of the regression models was confirmed again with the Fisher-Snedecor test ( $F$ criterion) and coefficient of determination $R^{2}$ for all analysed samples. The AIC value was used as a criterion for optimization between the proposed models and for choosing predictive variables.

\section{Results and discussion}

\section{Distribution coefficients}

The distribution coefficient, as a parameter describing sorption, is based on an assumption of a linear relationship between the absorbed and dissolved amounts of the radionuclide. It is often employed for sorption description due to its ease of use $[12,15,16]$. Under the assumption that the concentration of the sorbing substance in the system is very low, so the relationship of the substance concentration in solid and in water can be considered linear, the distribution coefficient can describe sorption with satisfactory accuracy. If the concentrations were higher, another type of isotherm (e.g. Langmuir or Freudlich isotherm) would have to be used to describe the relationship of the activity of the solid and liquid phase, as can be found in the review by Hinz [22].

Sorption batch experiments, conducted to determine distribution coefficients of selected anthropogenic radionuclides in sediment-water and suspended solids interfaces, showed that distribution coefficients vary depending on the nature of the radionuclide. In addition, differences were found between the two kinds of matrix (bottom sediment or suspended solids) and between the sampling sites. 
The average values of distribution coefficients, obtained for the sediment-water system, ranged from $2.6 \times 10^{1} \mathrm{l} / \mathrm{kg}$ $\left({ }^{131} \mathrm{I}\right)$ to $1.9 \times 10^{3} 1 / \mathrm{kg}\left({ }^{139} \mathrm{Ce}\right)$ across the monitored sampling sites included in the study. The average value of the sediment-water distribution coefficient decreases in the following sequence: ${ }^{139} \mathrm{Ce}>{ }^{134} \mathrm{Cs}>{ }^{133} \mathrm{Ba}>{ }^{241} \mathrm{Am}>{ }^{60} \mathrm{Co}>{ }^{85}$ $\mathrm{Sr}>{ }^{131} \mathrm{I}$, but this order can vary slightly at particular sites. For each of the radionuclides, the range of the evaluated distribution coefficients was fairly wide, sometimes in several orders of magnitude. An overview of the results of distribution coefficient determination in the bottom sediment-water system is specified in Table 3 .

Compared to sediment-water, distribution coefficients for suspended solids-water were higher at all studied locations. The average values of distribution coefficients obtained for the suspended solids-water system were from $1.0 \times 10^{3} \mathrm{l} /$ $\mathrm{kg}\left({ }^{85} \mathrm{Sr}\right)$ to $2.9 \times 10^{6} \mathrm{l} / \mathrm{kg}\left({ }^{60} \mathrm{Co}\right)$ across the monitored sampling sites. The average value of the suspended solids-water distribution coefficient decreases in the sequence: ${ }^{60} \mathrm{Co}>$ ${ }^{139} \mathrm{Ce}>{ }^{241} \mathrm{Am}>{ }^{133} \mathrm{Ba}>{ }^{131} \mathrm{I}>{ }^{134} \mathrm{Cs}>{ }^{85} \mathrm{Sr}$. As in the case of bottom sediment, this order was slightly different at some sites. The distribution coefficients for suspended solids, which were evaluated for the particular radionuclides, varied considerably. An overview of the results of distribution coefficient determination in suspended solids-water system is specified in Table 4. For the suspended solids-water interface, the ${ }^{85} \mathrm{Sr}$ distribution coefficient could not be evaluated in some cases with this experiment arrangement. Due to reluctant strontium sorption and the low level of suspended solids in the sample, ${ }^{85} \mathrm{Sr}$ activity absorbed by the solid phase was below the detection limit of the determination method in several experimental samples.

In addition, we compared our results with the data collected by IAEA [12], which originate from a number of studies and were determined under various conditions. Our results on distribution coefficients in suspended solids-water fit the IAEA range quite well for all monitored radionuclides. On the other hand, our data on distribution coefficients in bottom sediments-water, which are lower than those in the suspended solids-water system, lay below the IAEA data range in some cases. It is similar to data gained during insitu monitoring at Japanese coastal regions [23]. The longterm in-situ $K_{D}$ values are expected to be higher than our laboratory data with the 24-h contact time.

In our opinion, the difference between sorption of bottom sediments and suspended solids is caused by their different properties, especially grain size. The particles of solids suspended in the water column tend to be very fine with a large specific surface, while the active surface of sediments decreased as their grains aggregated in the riverbed during
Table 3 Values of distribution coefficients for studied radionuclides in bottom sediment-water interface in monitored sites and their comparison with data collected by IAEA [12]
Table 4 Values of distribution coefficients for studied radionuclides in suspended solids-water interface in monitored sites and their comparison with data collected by IAEA [12]

\begin{tabular}{lllllll}
\hline & \multicolumn{2}{l}{$K_{D}(\mathrm{l} / \mathrm{kg})$-measured } & & & $K_{D}(\mathrm{l} / \mathrm{kg})-\mathrm{IAEA}$ \\
\cline { 2 - 6 } & Arithmetic mean & $\mathrm{SD}$ & Minimum & Maximum & $\begin{array}{l}\text { Number of } \\
\text { values }\end{array}$ & $\begin{array}{l}\text { Minimum-maximum } \\
\end{array}$ \\
& & & & & & \\
\hline${ }^{60} \mathrm{Co}$ & $5.1 \mathrm{E}+02$ & $2.0 \mathrm{E}+02$ & $3.0 \mathrm{E}+02$ & $8.5 \mathrm{E}+02$ & 11 & $1.1 \mathrm{E}+03-1.7 \mathrm{E}+06$ \\
${ }^{85} \mathrm{Sr}$ & $4.7 \mathrm{E}+01$ & $2.5 \mathrm{E}+01$ & $1.0 \mathrm{E}+01$ & $9.8 \mathrm{E}+01$ & 15 & $1.4 \mathrm{E}+01-2.2 \mathrm{E}+03$ \\
${ }^{131} \mathrm{I}$ & $1.4 \mathrm{E}+01$ & $1.7 \mathrm{E}+01$ & $1.5 \mathrm{E}+00$ & $5.8 \mathrm{E}+01$ & 15 & $5.9 \mathrm{E}+01-3.4 \mathrm{E}+05$ \\
${ }^{133} \mathrm{Ba}$ & $5.7 \mathrm{E}+02$ & $3.2 \mathrm{E}+02$ & $1.6 \mathrm{E}+02$ & $1.3 \mathrm{E}+03$ & 15 & $2.5 \mathrm{E}+02-1.6 \mathrm{E}+04$ \\
${ }^{134} \mathrm{Cs}$ & $1.2 \mathrm{E}+03$ & $7.4 \mathrm{E}+02$ & $2.1 \mathrm{E}+02$ & $3.0 \mathrm{E}+03$ & 15 & $3.7 \mathrm{E}+02-1.9 \mathrm{E}+05$ \\
${ }^{139} \mathrm{Ce}$ & $3.2 \mathrm{E}+03$ & $4.0 \mathrm{E}+03$ & $5.1 \mathrm{E}+02$ & $1.3 \mathrm{E}+04$ & 9 & $4.2 \mathrm{E}+04-1.20 \mathrm{E}+06$ \\
${ }^{241} \mathrm{Am}$ & $2.7 \mathrm{E}+03$ & $5.4 \mathrm{E}+03$ & $2.1 \mathrm{E}+02$ & $1.9 \mathrm{E}+04$ & 10 & $2.5 \mathrm{E}+04-1.9 \mathrm{E}+06$ \\
\hline
\end{tabular}

\begin{tabular}{llllllll}
\hline & \multicolumn{2}{l}{$K_{D}(1 / \mathrm{kg})$-measured } & & \multicolumn{2}{l}{$K_{D}(1 / \mathrm{kg})-\mathrm{IAEA}$} \\
\cline { 2 - 6 } & Arithmetic mean & Standard deviation & Minimum & Maximum & $\begin{array}{l}\text { Number } \\
\text { of values }\end{array}$ \\
\hline${ }^{60} \mathrm{Co}$ & $3.8 \mathrm{E}+06$ & $7.7 \mathrm{E}+06$ & $5.9 \mathrm{E}+04$ & $3.1 \mathrm{E}+07$ & 15 & $1.1 \mathrm{E}+03-1.7 \mathrm{E}+06$ \\
${ }^{85} \mathrm{Sr}$ & $1.5 \mathrm{E}+03^{*}$ & $1.1 \mathrm{E}+03^{*}$ & $4.2 \mathrm{E}+02^{*}$ & $2.6 \mathrm{E}+03^{*}$ & $15^{*}$ & $1.4 \mathrm{E}+01-2.2 \mathrm{E}+03$ \\
${ }^{131} \mathrm{I}$ & $1.4 \mathrm{E}+04$ & $1.0 \mathrm{E}+04$ & $4.8 \mathrm{E}+03$ & $4.2 \mathrm{E}+04$ & 15 & $5.9 \mathrm{E}+01-3.4 \mathrm{E}+05$ \\
${ }^{133} \mathrm{Ba}$ & $1.4 \mathrm{E}+04$ & $1.7 \mathrm{E}+04$ & $3.7 \mathrm{E}+03$ & $7.5 \mathrm{E}+04$ & 15 & $2.5 \mathrm{E}+02-1.6 \mathrm{E}+04$ \\
${ }^{134} \mathrm{Cs}$ & $6.2 \mathrm{E}+03$ & $7.2 \mathrm{E}+03$ & $1.6 \mathrm{E}+03$ & $3.2 \mathrm{E}+04$ & 15 & $3.7 \mathrm{E}+02-1.9 \mathrm{E}+05$ \\
${ }^{139} \mathrm{Ce}$ & $1.2 \mathrm{E}+06$ & $9.1 \mathrm{E}+05$ & $2.2 \mathrm{E}+05$ & $2.8 \mathrm{E}+06$ & 15 & $4.2 \mathrm{E}+04-1.20 \mathrm{E}+06$ \\
${ }^{241} \mathrm{Am}$ & $1.1 \mathrm{E}+06$ & $1.9 \mathrm{E}+06$ & $1.0 \mathrm{E}+05$ & $7.9 \mathrm{E}+06$ & 15 & $2.5 \mathrm{E}+04-1.9 \mathrm{E}+06$ \\
\hline
\end{tabular}

*Values evaluated using the detection limit of ${ }^{85} \mathrm{Sr}$ in water. All distribution coefficients for ${ }^{85} \mathrm{Sr}$ were below these values 
the aging processes. The factor of grain size and specific surface of particles is anticipated to influence sorption in general, as mentioned by Singleton et al. [24]. Singleton also suggests another mechanism of sorption influence: pedogenic grain coatings.

\section{Relationship of sorption and sediment quality- simple regression}

Our findings on radionuclide sorption indicate that distribution coefficients depend heavily on local environmental conditions, especially on solid phase quality (mineralogical composition and grain structure) and water chemical composition. Even at sites located along a single river, the range of distribution coefficients was surprisingly wide for each radionuclide. In connection to this, we explored the rate of sorption in relation to sediment quality parameters. Unfortunately, the connection between radionuclide sorption and quality of suspended solids could not be evaluated due to an insufficient amount of suspended solids.

Firstly, we evaluated the distribution coefficient relationship of particular radionuclides with sediment quality parameters. Results confirm theoretical assumptions of a possible correlation between sorption of radionuclides $\left({ }^{85} \mathrm{Sr}\right.$, ${ }^{133} \mathrm{Ba}$ and ${ }^{134} \mathrm{Cs}$ ) and certain sediment quality parameters. Tables attached as electronic supplementary information (Tables 1-3), published online along with this article, show the results of simple regression analysis where a correlation was observed.

For parameters of sediment granularity, a correlation was confirmed only for sorption of ${ }^{85} \mathrm{Sr}\left(d_{50}\right.$ and silt). Contrary to our expectations, the influence of granularity was not identified for any other radionuclide except ${ }^{85} \mathrm{Sr}$. The relationship between $K_{D}\left({ }^{85} \mathrm{Sr}\right)-d_{50}$ decreases, while the relationship between $K_{D}\left({ }^{85} \mathrm{Sr}\right)$-silt shows upward trends, as shown in Fig. 2a, b. This is in harmony with the assumption that fine fractions are mainly responsible for radionuclide fixation, as explored by Korobova et al. [25]. Sorption rises with decreasing granularity, as the specific surface available for sorption increases.

In connection to the effect of sediment mineralogical composition on radionuclide sorption, it is important to note that we supposed that all radionuclides exist in their ionic forms. According to Eh-pH data [26], most of the studied radionuclides are present in cationic forms $\mathrm{CO}^{2+}$, $\mathrm{Sr}^{2+}, \mathrm{Ba}^{2+}, \mathrm{Cs}^{+}, \mathrm{Ce}^{3+}, \mathrm{Am}^{3+} / \mathrm{AmOH}^{2+}$ ), with the exception of radioiodine, which is assumed to occur in anionic form $\left(\mathrm{I}^{-}\right)$, considering the $\mathrm{pH}$ and Eh potential common in surface waters. The chemical forms of radionuclide occurrence can be more complex under experimental conditions, since more factors can affect them, for example presence of ligands, which can form complexes with radionuclide ions.
Considering mineralogical composition, correlations between feldspar content and sorption of ${ }^{133} \mathrm{Ba}$ and ${ }^{134} \mathrm{Cs}$ were found, both cases having increasing trends. For these two radionuclides, decreasing relationships between their sorption and quartz content in the sediment were also identified (see Fig. 3c-e). Similar findings for ${ }^{134}$ Cs sorption in soils were published by Miecznik [27]. Quartz is a mineral generally considered to show low sorption properties. Its structure, which is built of $\mathrm{SiO}_{4}$ tetrahedrons, is electrically neutral. If $\mathrm{Si}^{4+}$ ions are substituted with $\mathrm{Al}^{4+}$, as in case of feldspar, the electro neutrality is disrupted and conditions suitable for cation sorption are engendered, as described by Richter [28]. Similar mechanism can be assumed for the increasing relationship of mica content and sorption of ${ }^{85} \mathrm{Sr}$ and ${ }^{133} \mathrm{Ba}$, which is displayed in Fig. 3f).

In connection to the presumption that organic matter in sediments tends to retain cations, because of the presence of the dissociated hydroxyl and carboxyl groups, we expected to find correlations between organic matter content and cation sorption. Though direct dependence of sorption on organic matter content was identified for ${ }^{85} \mathrm{Sr}$ and ${ }^{133} \mathrm{Ba}$ (see Fig. 3g), for other radionuclides in cationic form it was not. According to Santschi [29], organic matter can significantly influence radionuclide sorption, but whether it causes sorption to increase or decrease strongly depends on other conditions.

\section{Relationship of sorption and sediment quality- multiple regression}

The evaluation results obtained using simple regression show that for all the studied radionuclides, none of the tested sediment quality parameters influenced sorption in a universal way. Sorption of a particular radionuclide tends to be affected by a specific group of quality parameters, which can vary for different radionuclides. A sediment quality parameter that affects the sorption of one radionuclide does not necessarily influence the sorption of another. For this reason, multiple regression was employed to evaluate the coincidental effect of several possible factors (quality parameters). A significant correlation with multiple parameters was found for the sorption of ${ }^{131} \mathrm{I}\left(d_{50}\right.$, Feldspar, organic matter and mica), ${ }^{133} \mathrm{Ba}\left(d_{50}\right.$ and mica), ${ }^{134} \mathrm{Cs}$ (silt, quartz and organic matter), ${ }^{139} \mathrm{Ce}$ (silt, feldspar and organic matter), and ${ }^{241} \mathrm{Am}$ (silt, feldspar and organic matter). The regression parameters are attached as supplementary information (Table 4).

No multiple correlations were found for ${ }^{60} \mathrm{Co}$ and ${ }^{85} \mathrm{Sr}$. Their fixation onto sediments can be affected by factors which were not explored here, such as content of ferric and manganese oxides [30]. 
Fig. 3 Significant relationships of radionuclide sorption and sediment quality identified by simple regression (a)

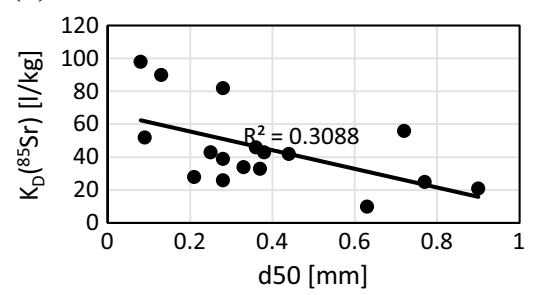

(c)

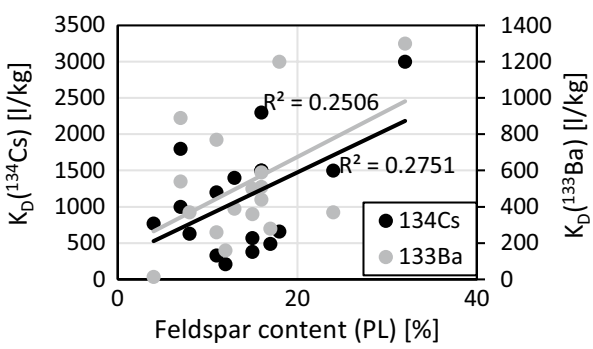

(e)

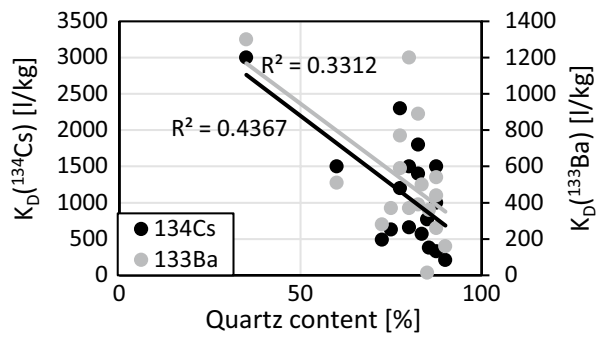

(g)

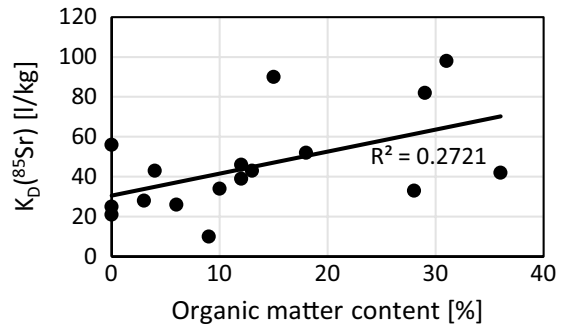

(b)

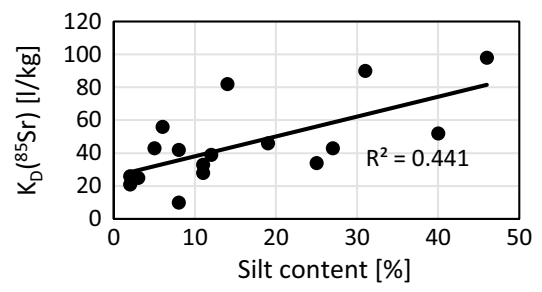

(d)

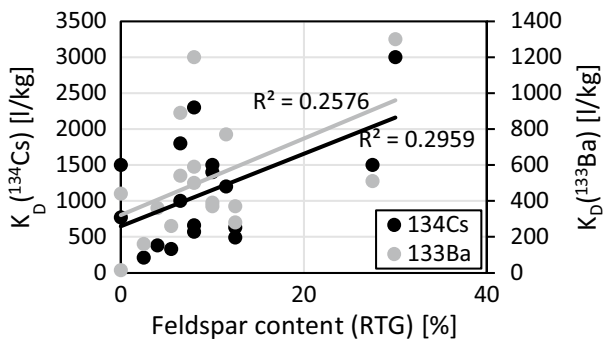

(f)

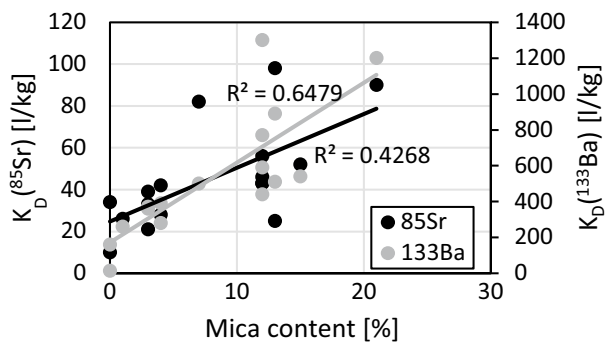

\section{Conclusion}

This study is concerned with sorption of anthropogenic radionuclides in the hydrosphere, namely onto river bottom sediments and solids suspended in river water. Sorption is characterized using distribution coefficients, which were determined using a batch method. The data obtained in our study showed surprising variability, so we tried to find the reason for that by analysing sediment mineralogical composition.

The differences in sorption of radionuclides caused by sediment granularity and mineralogical composition were explored. Since radionuclide sorption is influenced by several parameters, multiple regression evaluation was employed alongside simple regression. Sorption of most of the studied radionuclides is affected by sediment granularity ( $d_{50}$ or silt content) together with other factors (mineralogical composition depending on the particular radionuclide).

Variations in measured $K_{D}$ values were partly explained by the diversity of sediment properties, but it is also obvious that there are other factors influencing radionuclide interaction with sediments, such as the conditions of the surrounding environment (temperature or water composition, including presence of competing ions or organic or inorganic ligands, forming complexes) [19].

Despite observing certain regularities in sorption of radionuclides in connection to sediment properties, it is important to remember that the interaction of radionuclides with solids in the hydrosphere is site-specific. Modelling radionuclide transport or behaviour at a particular location 
using sorption parameters measured elsewhere or for another substance can be very inaccurate. Since sorption can significantly influence radionuclide fate in the hydrosphere, we recommend using the appropriate data on sorption, whenever they are available or it is possible to acquire them.

\section{Conflict of interest}

The authors declare that they have no conflict of interest.

Acknowledgements This work was prepared with the support of project VG20122015088 sponsored by the Czech Ministry of Interior.

Open Access This article is licensed under a Creative Commons Attribution 4.0 International License, which permits use, sharing, adaptation, distribution and reproduction in any medium or format, as long as you give appropriate credit to the original author(s) and the source, provide a link to the Creative Commons licence, and indicate if changes were made. The images or other third party material in this article are included in the article's Creative Commons licence, unless indicated otherwise in a credit line to the material. If material is not included in the article's Creative Commons licence and your intended use is not permitted by statutory regulation or exceeds the permitted use, you will need to obtain permission directly from the copyright holder. To view a copy of this licence, visit http://creativecommons.org/licenses/by/4.0/.

\section{References}

1. Hanslík E, Marešová D, Juranová E (2013) Radioactive background in hydrosphere prior to planned extension of nuclear power plant. Int J Nucl Energy Sci Eng 3:47-55

2. International Atomic Energy Agency (2006) Environmental consequences of the chernobyl accident and their remediation: twenty years of experience. Report of the UN Chernobyl Forum Expert Group "Environment" (EGE). Vienna

3. Maringer FJ et al (2009) Long-term monitoring of the Danube river-sampling techniques, radionuclide metrology and radioecological assessment. Appl Radiat Isotopes. https://doi. org/10.1016/j.apradiso.2009.01.053

4. Navas A et al (2011) Radionuclides and stable elements in the sediments of the Yesa Reservoir Central Spanish Pyrenees. J Soils Sediments. https://doi.org/10.1007/s11368-011-0401-0

5. Konoplev A et al (2016) Behavior of accidentally released radiocesium in soil-water environment: looking at Fukushima from a Chernobyl perspective. J Environ Radioact. https://doi. org/10.1016/j.jenvrad.2015.06.019

6. Yoshimura $\mathrm{K}$ et al (2015) An extensive study of the concentrations of particulate/dissolved radiocaesium derived from the Fukushima Dai-ichi Nuclear Power Plant accident in various river systems and their relationship with catchment inventory. J Environ Radioact. https://doi.org/10.1016/j.jenvrad.2014.08.021

7. Ambe D et al (2014) Five-minute resolved spatial distribution of radiocesium in sea sediment derived from the Fukushima Dai-ichi Nuclear Power Plant. J Environ Radioact. https://doi. org/10.1016/j.jenvrad.2014.09.007

8. Evrard O et al (2016) Quantifying the dilution of the radiocesium contamination in Fukushima coastal river sediment (2011-2015). Sci Reports. https://doi.org/10.1038/srep34828
9. European Nuclear Safety Regulators Group (2012) Peer review country report, Czech Republic

10. Eyrolle F et al (2012) Consequences of hydrological events on the delivery of suspended sediment and associated radionuclides from the Rhône River to the Mediterranean Sea. J Soils Sediments. https://doi.org/10.1007/s11368-012-0575-0

11. Hanslík E et al (2009) Monitoring and assessment of radionuclide discharges from Temelín Nuclear Power Plant into the Vltava River (Czech Republic). J Environ Radioact. https://doi. org/10.1016/j.jenvrad.2008.11.001

12. International Atomic Energy Agency (2010) Handbook of parameter values for the prediction of radionuclide transfer in terrestrial and freshwater environments. Vienna

13. US Environmental Protection Agency (1991) Batch-type procedures for estimating soil adsorption for chemicals

14. ASTM C1733 - 10 (2002) Standard Test Method for Distribution Coefficients of Inorganic Species by the Batch Method. West Conshohocken, PA, USA : ASTM International, DOI 10.1520/C1733-10

15. Das DK et al (2011) Sorption of Am(III) on natural sediment: experiment and modelling. J Radioanal Nucl Chem. https://doi. org/10.1007/s10967-011-1045-7

16. Ciffroy P, Durrieu G, Garnier J-M (2009) Probabilistic distribution coefficients (Kds) in freshwater for radioisotopes of $\mathrm{Ag}$, $\mathrm{Am}, \mathrm{Ba}, \mathrm{Be}, \mathrm{Ce} \mathrm{Co}, \mathrm{Cs}, \mathrm{I}, \mathrm{Mn}, \mathrm{Pu}, \mathrm{Ra}, \mathrm{Ru}, \mathrm{Sb}, \mathrm{Sr}$ and $\mathrm{Th}-$ implications for uncertainty analysis of models simulating the transport of radionuclides in rivers. J Environ Radioact 1:2. https://doi.org/10.1016/j.jenvrad.2008.10.019

17. Granados $\mathrm{F}$ et al (2006) 60Co aqueous speciation and $\mathrm{pH}$ effect on the adsorption behavior on inorganic materials. Appl Radiat Isotopes. https://doi.org/10.1016/j.apradiso.2005.06.016

18. Kaplan DI, Serkiz SM, Allison JD (2010) Europium sorption to sediments in the presence of natural organic matter: a laboratory and modelling study. Appl Geochem. https://doi.org/10.1016/j. apgeochem.2009.11.007

19. Perez FF et al (2015) Adsorption and desorption kinetics of $60 \mathrm{Co}$ and $137 \mathrm{Cs}$ in fresh water rivers. J Environ Radioact. https ://doi.org/10.1016/j.jenvrad.2015.07.010

20. Juranová E, Hanslík E (2015) Determination of sorption characteristics for artificial radionuclides in the hydrosphere. J Radioanal Nucl Chem. https://doi.org/10.1007/s10967-014-3665-1

21. ISO 10703:2007 Water quality-determination of the activity concentration of radionuclides - method by high resolution gamma-ray spectrometry

22. Hinz C (2001) Description of sorption data with isotherm equations. Geoderma 99:225-243. https://doi.org/10.1016/S0016 $-7061(00) 00071-9$

23. Takata $\mathrm{H}$ et al (2016) A new approach to evaluate factors controlling elemental sediment-seawater distribution coefficients $(\mathrm{Kd})$ in coastal regions, Japan. Sci Total Environ. https://doi. org/10.1016/j.scitotenv.2015.11.034

24. Singleton AA et al (2017) Effects of grain size, mineralogy, and acid-extractable grain coatings on the distribution of the fallout radionuclides $\mathrm{Be}-7, \mathrm{Be}-10, \mathrm{Cs}-137$, and $\mathrm{Pb}-210$ in river sediment. Geochim Cosmochim Acta. https://doi.org/10.1016/j. gca.2016.10.007

25. Korobova EM, Linnik VG, Brown J (2015) Distribution of artificial radioisotopes in granulometric and organic fractions of alluvial soils downstream from the Krasnoyarsk Mining and Chemical Combine (KMCC), Russia. J Soils Sediments. https ://doi.org/10.1007/s11368-015-1268-2

26. Takeno N (2005) Atlas of Eh-pH diagrams: Intercomparison of thermodynamic databases. Research Center for Deep Geological Environments, National Institute of Advanced Industrial Science and Technology, Geological Survey of Japan 
27. Miecznik M et al (2018) Study on the sorption process on geological materials of long-lived radioactive isotopes $90 \mathrm{Sr}$ and $137 \mathrm{Cs}$ in model systems with the use of short-lived isotopes of 85Sr, 134Cs. J Radioanal Nucl Chem. https://doi.org/10.1007/ s10967-018-5742-3

28. Richter C (2015) Sorption of environmentally relevant radionuclides (U(VI), $\mathrm{Np}(\mathrm{V})$ ) and lanthanides (Nd(III)) on feldspar and mica. Ph.D thesis, Technical University Dresden

29. Santschi PH et al (2017) Iodine and plutonium association with natural organic matter: a review of recent advances. Appl Geochem. https://doi.org/10.1016/j.apgeochem.2016.11.009

30. Rumynin VG, Nikulenkov AM (2016) Geological and physicochemical controls of the spatial distribution of partition coefficients for radionuclides (Sr-90, Cs-137, Co-60, Pu-239, 240 and Am-241) at a site of nuclear reactors and radioactive waste disposal (St Petersburg region, Russian Fede. J Environ Radioact. https://doi.org/10.1016/j.jenvrad.2016.05.030

Publisher's Note Springer Nature remains neutral with regard to jurisdictional claims in published maps and institutional affiliations. 